\title{
Copper-Catalyzed Hydroarylation Reaction
}

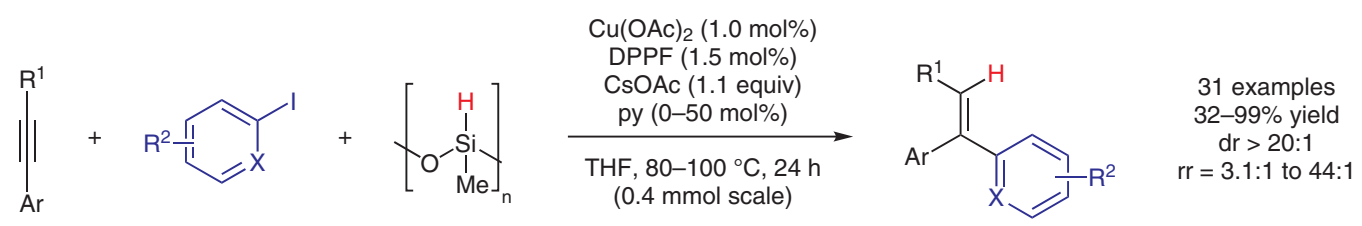

Metal-Catalyzed

Asymmetric

Synthesis and

Stereoselective

Reactions

Selected examples:<smiles>C(=C/c1ccccc1)\c1ccccc1</smiles><smiles>C(=C/c1ccccn1)\c1ccccc1</smiles><smiles>COc1cccc(/C(=C/c2ccccc2)c2ccccc2)c1</smiles><smiles>Brc1ccc(/C=C/c2ccccc2)cc1</smiles><smiles>CC/C=C/c1cccc(OC)c1</smiles>

93\% yield

$65 \%$ yield $75 \%$ yield 93\% yield $24 \%$ yield<smiles>CC=C(c1ccccc1)c1ccccc1</smiles><smiles>CC=C(c1ccccc1)c1cccnc1</smiles><smiles>CC=C(c1ccccc1)c1ccc(C)cc1</smiles><smiles>CC=C(c1ccccc1)c1ccc([Se-])cc1</smiles>

$63 \%$ yield $\mathrm{rr}=44: 1$ (2.0 mmol scale)<smiles>COc1cccc(/C(=C/C(C)(C)C)c2ccccc2)c1</smiles>
$61 \%$ yield $2.0 \mathrm{mmol}$ scale)<smiles>CCNC/C=C(\c1ccccc1)c1ccc(C(F)(F)F)cc1</smiles>

$56 \%$ yield
$60 \%$ yield $\mathrm{rr}=26: 1$<smiles>[Z20][R6]([H])([H])/C=C(/c1ccccc1)c1ccc(C2(C)CC2)cc1</smiles>
$79 \%$ yield rr $=21: 1$<smiles>CC=CC1(C)OCCO1</smiles>
$78 \%$ yield
$\mathrm{rr}=29: 1$

Proposed mechanism:<smiles>COc1cccc(/C(=C/CCOc2ccccc2)c2ccccc2)c1</smiles>

$91 \%$ yield

$\mathrm{rr}=9.7: 1$

[Si] $-\mathrm{H}$

\section{Key words}

\section{copper catalysis}

trisubstituted

olefins

hydroarylation
Significance: The stereoselective synthesis of trisubstituted olefins has attracted considerable attention due to the prevalence of such structural motifs in pharmaceuticals and as valuable synthetic building blocks. In this paper, the authors present a stereoselective copper-catalyzed hydroarylation of internal alkynes for the synthesis of 1,1-diaryl trisubstituted olefins.

SYNFACTS Contributors: Mark Lautens, Ivan Franzoni

Synfacts 2017, 13(11), 1155 Published online: 19.10.2017 Dol: 10.1055/s-0036-1591388; Reg-No.: L11517SF
Comment: The combination of a copper(II) catalyst, polymethylhydrosiloxane as hydride source, and additives allowed the reaction between internal alkynes and several aryl iodides. The corresponding products were generally obtained in good to excellent yields and with high regioselectivities. Several $2.0 \mathrm{mmol}$ scale reactions were demonstrated. 